\title{
Temporal and Spatial Distribution of the Ichthyofauna in Two Streams of the Upper Rio Paraná Basin
}

\author{
Carla Simone Pavanelli $^{1 *}$ and Érica Pellegrini Caramaschi ${ }^{2}$ \\ ${ }^{1}$ Nupélia/ Universidade Estadual de Maringá; Av. Colombo, 5790; carlasp@nupelia.uem.br; CEP 87020-900; \\ Maringá - PR - Brazil. ${ }^{2}$ Departamento de Ecologia; IB; CCS; UFRJ; Ilha do Fundão; C. P. 6802; \\ erica@biologia.ufrj.br; CEP 21941-970; Rio de Janeiro - RJ - Brazil
}

\begin{abstract}
The temporal and spatial distribution of the ichthyofauna was assessed in two streams, Caracu and São Pedro, affluents of the Rio Paraná, from March 1991 through February 1992. Samples were taken along the streams, using sieves (three sites on the Caracu and two on the São Pedro), and gill nets (two sites on the São Pedro). A total of 6,664 specimens belonging to 71 species were captured. CPE was calculated for each fishing gear. The data for cumulative frequency indicated that only the mouths of streams did not reach an asymptote. Constancy analysis showed that occasional and accessory species predominated. The spectrum of spatial diversity indicated that diversity increased toward the mouth of streams and temporal diversity increased in the high water season. The results of correspondence analysis for sieved fishes and Sørensen similarity for netted ones showed that the sites located at the same position on the streams were more similar than between adjacent sites in the same stream.
\end{abstract}

Key words: Community structure, freshwater fishes, stream ecology

\section{INTRODUCTION}

The western side of the Rio Paraná in Brazilian territory has been studied for several years by the Nupélia (Center for Research in Limnology, Ichthyology, and Aquaculture) of the State University of Maringá (Vazzoler et al., 1997). These studies revealed that the floodplain contains a high biological diversity and that it is of fundamental importance for the maintenance of viable populations of species already eliminated in the upper stretches of that basin, especially with regard to large-sized fishes that undertake extensive reproductive migrations (Agostinho and Zalewski, 1996). However, the contribution and/or importance of small lotic environments to these populations are not well known so far. The present study extended these investigations to the eastern bank, treating small lotic bodies of water. The Rio Paraná eastern bank is elevated in the region, so that only the lower parts of the affluents are influenced by the hydrological regime of the river. The ichthyofauna distribution along of two streams was determined, analyzing the spatial and temporal aspects and comparing one to another and, as far as possible, with data from the Rio Paraná itself.

\footnotetext{
* Author for correspondence
} 


\section{MATERIALS AND METHODS}

Study area - Samples were taken at six sites located along the Caracu and the São Pedro streams (Fig. 1). These streams, affluents of the Rio Paraná eastern side, are second and third order respectively according to the classification by Jeffries and Mills (1990). Their mouths are about two $\mathrm{km}$ apart. The Caracu is about $5.2 \mathrm{~km}$ long, springs at the $320 \mathrm{~m}$ contour line, and has degraded shoreline forest limited to a few sites. The São Pedro is about $19.2 \mathrm{~km}$ long, springs at the $340 \mathrm{~m}$ contour line, and has poorly developed riparian forest.

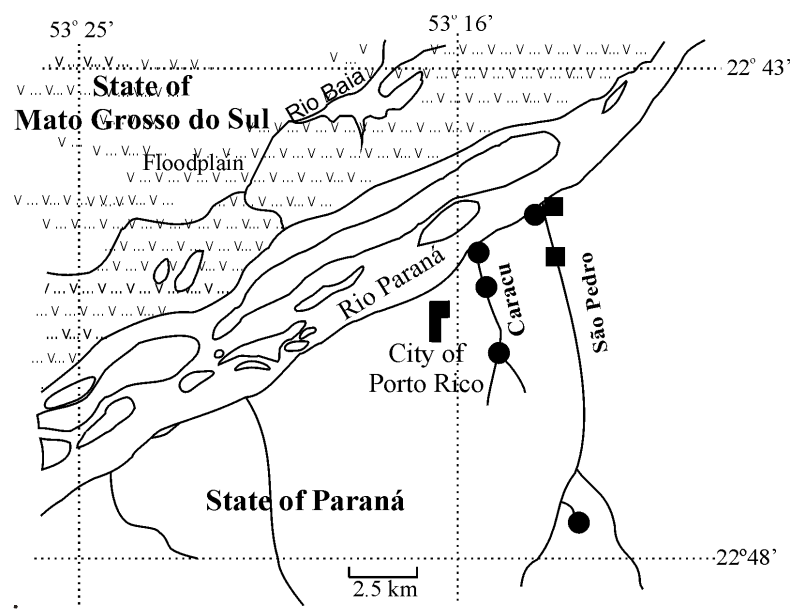

Figure 1 - Location of the sampling sites in the Caracu and São Pedro streams (circles - collected with sieves; squares - collected with gill nets).

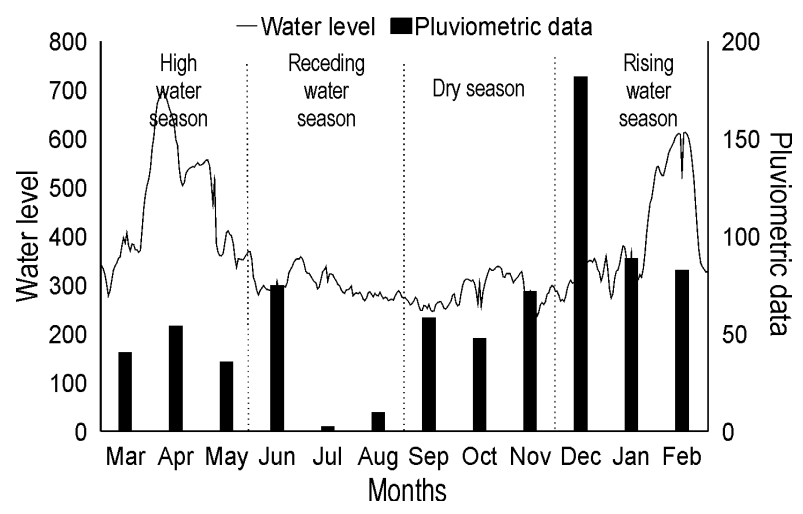

Figure 2 - Monthly pluviometric data $(\mathrm{mm})$ and water level $(\mathrm{cm})$ taken in main channel of Rio Paraná, Porto Rico region, State of Paraná, by the National Department of Water and Electric Energy and by São José harbor climatologic station, respectively.
The Rio Paraná water level, the seasons' characterization (based on water level data), and the pluviometric data for the region during the study period are shown in Fig. 2.

The spatial and temporal variation of some limnological parameters of the streams has been described by Pavanelli et al. (1997). They found that there was a reduction of variability (increase in the buffering capacity) along the upperdownstream direction. They also suggested that the total-P was the variable with the highest coefficients of variation.

Caracu. - The sampling station at the headwater was located at the place where the stream has been artificially widened to about $10 \mathrm{~m}$ and $0.95 \mathrm{~m}$ mean depth, creating a lentic situation. The sieves were passed longitudinally for $20 \mathrm{~m}$ at this site. The intermediary site was a semi-lotic environment, also artificially widened to about 10 $\mathrm{m}$ wide, with a mean depth of $0.70 \mathrm{~m}$. There, the sieves were passed for about $15 \mathrm{~m}$. The mouth, with a mean width of $8 \mathrm{~m}$ and mean depth of $1 \mathrm{~m}$, was sieved for about $30 \mathrm{~m}$. This was a lotic environment where water level fluctuated highly, influenced by the Rio Paraná level mainly during rising and high water seasons.

São Pedro. - The site in the headwater had a mean width of $2 \mathrm{~m}$ and depth of about $0.20 \mathrm{~m}$ and was sieved for $130 \mathrm{~m}$. The intermediary site, about $1.60 \mathrm{~m}$ deep and $3 \mathrm{~m}$ wide, had fast current and high banks. Its physiography did not allow the use of sieves at that sampling site. The mouth, about $25 \mathrm{~m}$ wide and $2.00 \mathrm{~m}$ in mean depth, had fast flowing water and was sieved for $30 \mathrm{~m}$.

Sampling and data collection - Samples were taken monthly from March 1991 through February 1992. Each stream was sampled at three sites, at its headwater, its mouth, and at an intermediary site near the mouth (Fig. 1). Due to physiographic differences on the sites, Caracu was sampled only by sieves and São Pedro by sieves at the headwaters, by gill nets at the intermediary site and at the mouth by both of the fishing gears. Two collectors used two sieves at the same time, and they were passed in the shallow waters, mainly under the aquatic macrophytes for 40 minutes. The standard lengths in millimeters of the specimens captured with sieves were measured, after species identification. At the São Pedro intermediary site and at the mouth, gill nets, $10 \mathrm{~m}$ long and mesh 
sizes of $3,4,5$, and $6 \mathrm{~cm}$ were set up. The first two gill nets were $1.20 \mathrm{~m}$ high, and the last two were $1.50 \mathrm{~m}$ high. At the mouth, an additional trammel net, $10 \mathrm{~m}$ long and $1.50 \mathrm{~m}$ high with $6 \mathrm{~cm}$ mesh was also set up. The nets were placed at sunset and checked twice, at night and at dawn. Nupélia/Finep (1989) collected data on the occurrence and constancy of the species in the Rio Paraná. These data were obtained by different methods and at different times than the present study, and are included here only for qualitative comparison purposes. The specimens taken with nets, after identification, had their standard length measured in millimeters and total weight in grams, and were dissected to identify their sex and gonadal stage. Pavanelli (1994) gives a more detailed analysis of the reproductive biology of the most abundant species. Pavanelli and Caramaschi (1997) provided a taxonomic list and discussion of the ichthyofauna composition of both streams. Regarding this taxonomic list, in the present paper Astyanax bimaculatus (Linnaeus, 1758) $=A$. altiparanae Garutti and Britski, 2000; Aphyocharax nasutus Ahl, $1936=$ A. cf. anisitsi Eigenmann and Kennedy, 1903; Cheirodon notomelas Eigenmann, $1915=$ Serrapinnus notomelas (Eigenmann, 1915); Cheirodon sp. = Serrapinnus sp.; Hyphessobrycon callistus (Boulenger, 1900) $=H$. eques (Steindachner, 1882); Jobertina sp. $=$ Characidium sp.; Myloplus levis $($ Eigenmann and McAtee, 1907) $=$ M. tiete Eigenmann and Norris, 1900; Parodon tortuosus Eigenmann and Norris, $1900=P$. nasus Kner, 1859; Auchenipterus nuchalis $($ Spix, 1829) $=$ A. osteomystax (Ribeiro, 1918); Hypostomus aff. derbyi (Haseman, 1911) $=H$. ancistroides (Ihering, 1911); and Rhamphichthys rostratus $($ Linnaeus, 1766) $=$ R. hahni $($ Meinken, 1937) .

Data analysis - The abundance of each species was determined by the CPE (catch per effort). Sieved fishes are expressed in number of individuals caught by sieve in 6 hours, and the netted ones are expressed in number of individual caught by $1,000 \mathrm{~m}^{2}$ of gill nets in $12 \mathrm{~h}$. The species whose relative abundance was higher than five percent were considered abundant.

The constancy was calculated from the frequency with which each species was recorded in the samples, constancy (c) being the relationship expressed as the percent $c=(p \times 100) / P$, where $p$ was the number of samples containing the species in question and $\mathrm{P}$ was the total number of collections (Dajoz, 1983). A species was considered constant when this percentage exceeded 50\%, accessory between 25 and $50 \%$, and occasional below $25 \%$.

The cumulative frequency was obtained from the cumulative occurrence of the species in the collections for the entire sampling period.

The Shannon-Wiener index $\left(H^{\prime}\right)$ was used to calculate species diversity, based on the formula $H^{\prime}=\sum_{i=1}^{s}\left(p_{i}\right)\left(\log _{2} p_{i}\right)$, where $S$ was the number of species collected and $p_{i}$ was the proportion of the total sample belonging to the species $i$. Evenness $(E)$ was calculated from the equation $E=D / D_{M A X}$, where $D$ was the observed index of species diversity and $D_{M A X}$ was the maximum possible diversity index, given $S$ species and $N$ individuals. The calculations were processed with the aid of Divers ${ }^{\circledR}$ software, based on the formulas described above and proposed by Krebs (1989).

Correspondence analysis was calculated for sieved fishes to achieve summaries of the patterns in species-sites relationships, as suggested by Jackson (1997). The software used for that was NTSYS-PC ${ }^{\circledR}$, version 1.50. Similarity $(I)$ was calculated for netted fishes from Sørensen index (Legendre and Legendre, 1983), the formula for which is $I=(2 a) / 2 a+b+c$, where $a$ is the number of species common to two sites, $b$ is the number of species exclusive to one of the sites being compared, and $c$ is the number of species exclusive to the other site. Fishes collected in Rio Paraná by Nupélia/Finep (1989) were included for comparison in constancy and similarity analysis, both based on qualitative data, only for netted fishes. The Shannon-Wiener index and the correspondence analysis were calculated on CPE data.

\section{RESULTS}

Faunistic comparisons - In the two streams, 71 fish species of 21 families were collected, as listed by Pavanelli and Caramaschi (1997).

Sieve samples. - A total of 2,834 specimens were collected using sieves. The total CPE was 25,510. Species considered abundant were Serrapinnus notomelas, Phalloceros caudimaculatus, Cichlasoma paranaense, Astyanax altiparanae, Aphyocharax cf. anisitsi, Hypostomus ancistroides 
and Hoplias aff. malabaricus; these represented $82.7 \%$ of the total CPE. The Caracu contributed much higher CPE than the São Pedro, 17,716 vs. 7,794, respectively. The Caracu headwater yielded a lower CPE $(4,189)$, while the intermediary site $(6,997)$ and the mouth $(6,529)$ did not show marked difference in abundance. For the São Pedro, the difference between the headwater and the mouth was large, CPE 153 vs. 7,641, respectively.

The results for species constancy at the different sampling sites of the two streams are shown in Fig. 3. It showed that excepting Caracu headwater, all the sampling sites presented more occasional species than accessories and constants. The data for cumulative frequency indicated that only the mouths of the streams did not reach an asymptote (Fig. 4).

The diversity results are expressed in the form of a spectrum of diversity, as proposed by Margalef (1986), adding the samples spatially (Fig. 5) and temporally (Fig. 6) for each stream. Both of them revealed diagonal patterns, but it is more marked spatially.

Fig. 7 shows the correspondence analysis between species and sampling sites sampled by sieves, in both streams.

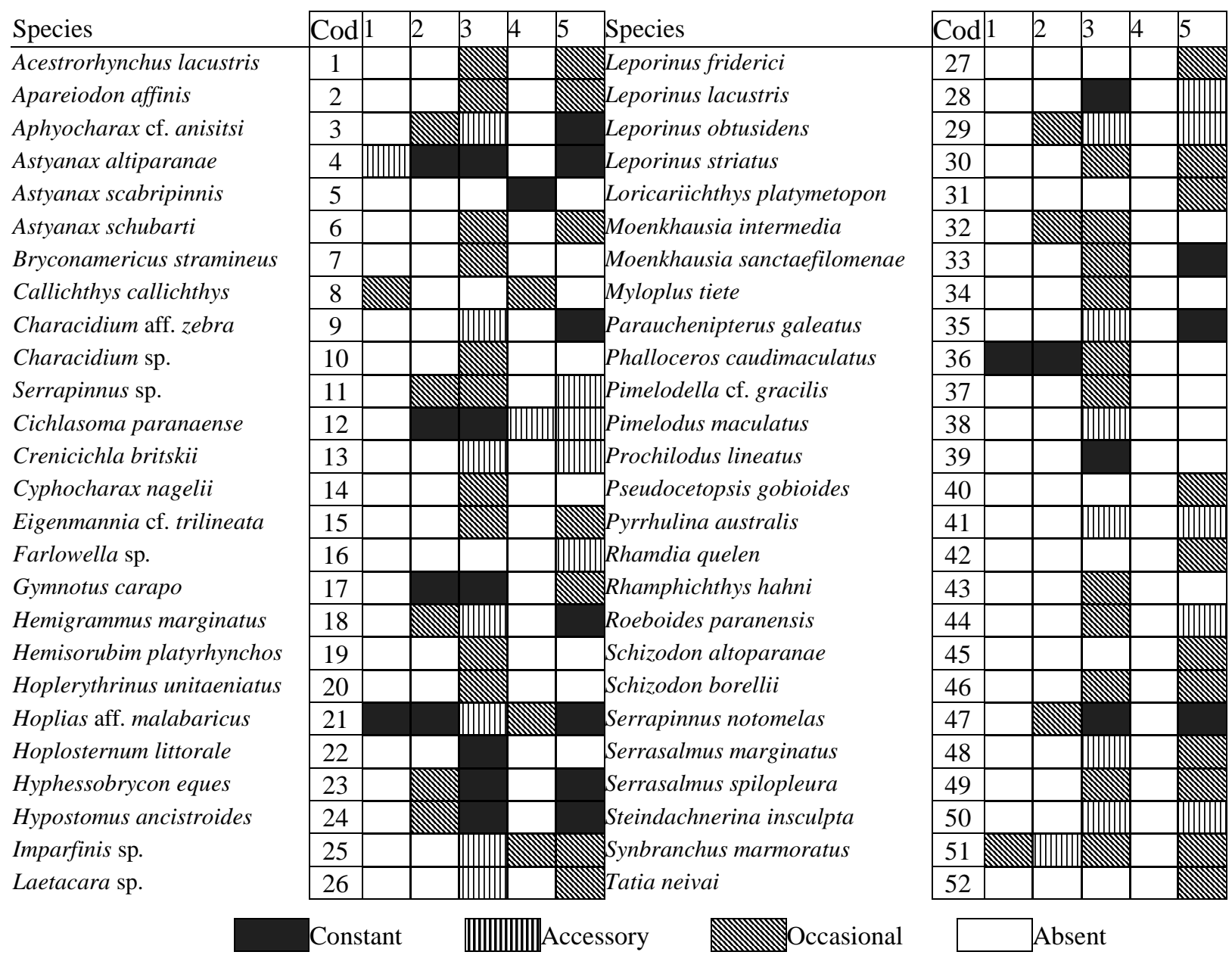

Figure 3 - Constancy and codes (cod.) of the species collected with sieves in the sites represented by: 1. Caracu-headwater, 2. Caracu-intermediary, 3. Caracu-mouth, 4. São Pedro-headwater and 5. São Pedromouth.

The stream's headwaters were not so close, but the mouths were closer to each other, and the intermediary site was in an intermediate position (Fig. 7B). Astyanax scabripinnis (species code 5) was found only in S. Pedro headwater, and this species is placed in Fig. 7A in a similar position of that environment in the Fig. 7B. 


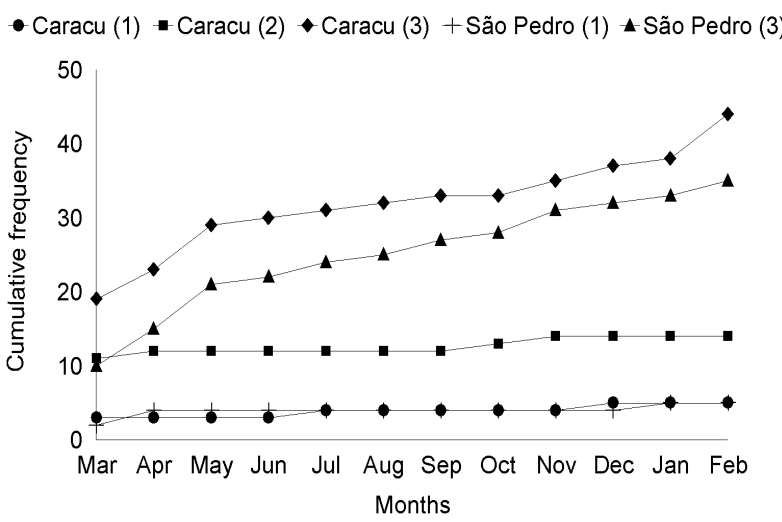

Figure 4 - Cumulative frequency for the species collected with sieves in the Caracu and São Pedro streams, being (1) headwater, (2) intermediary and (3) mouth.

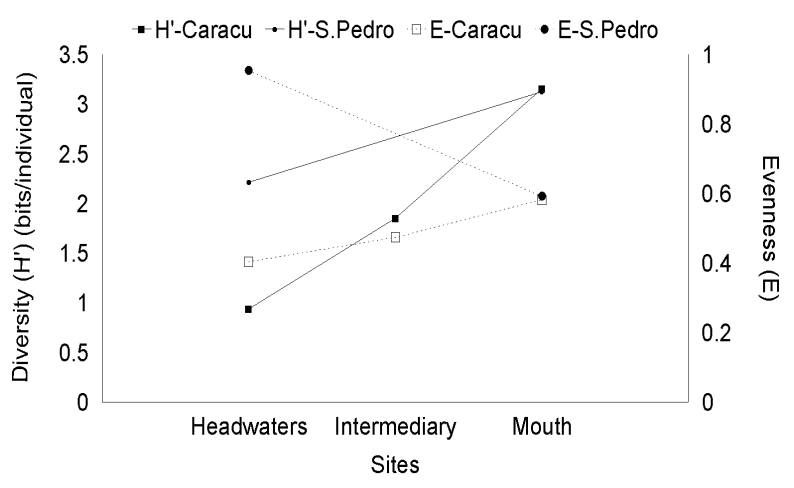

Figure 5 - Spectrum of spatial diversity based on Shannon-Wiener index $\left[H^{\prime}\right]$, and evenness $[E]$, for the fishes collected with sieves in the Caracu and São Pedro streams.

A

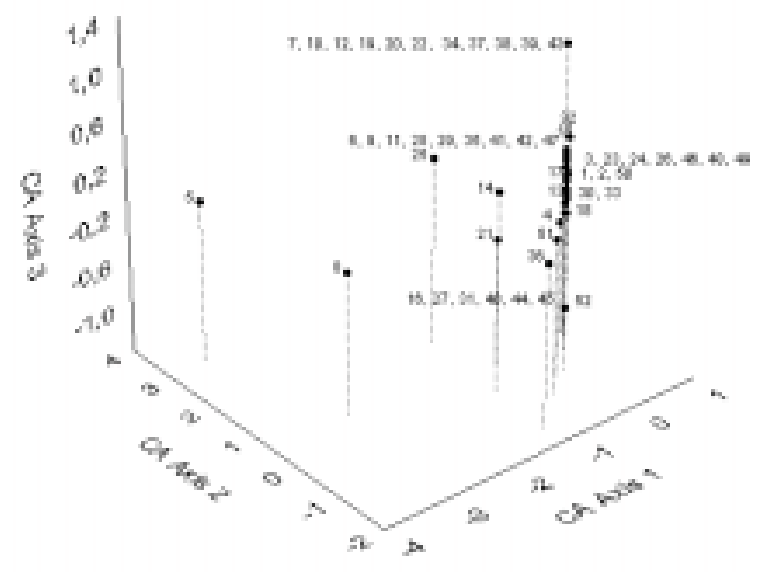

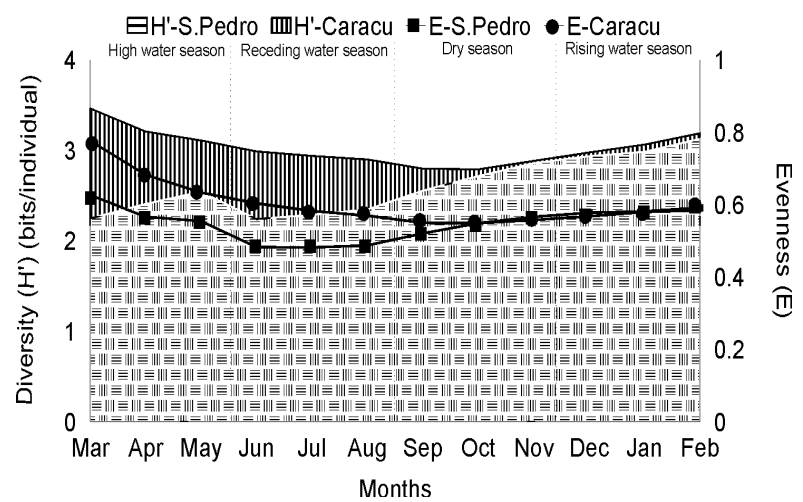

Figure 6 - Spectrum of temporal diversity based on Shannon-Wiener index [H'] (areas) and evenness $[E]$ (lines), for the species collected with sieves in the Caracu and São Pedro streams.

Callichthys callichthys (code 8) occurred exclusively in both headwaters, and its position was in an intermediary place (Fig. 7A) between the two headwaters (Fig. 7B).

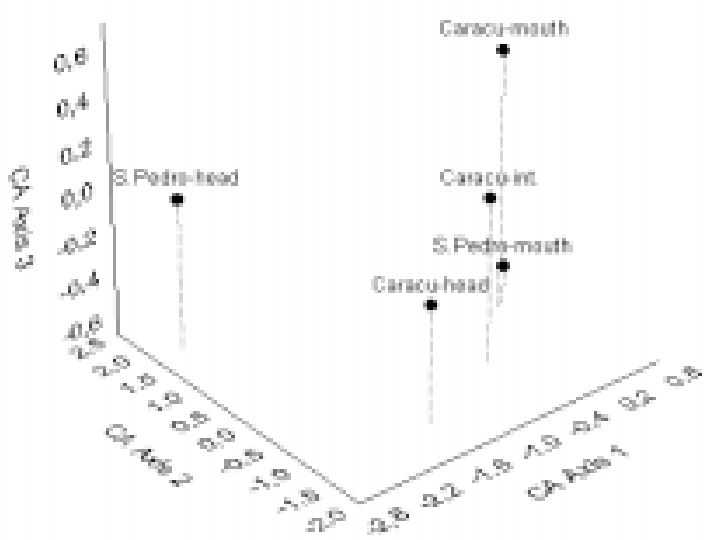

Figure 7 - Results of correspondence analysis. (A) Species scores (species codes in Fig. 3); (B) sites scores sampled by sieves, in the Caracu and São Pedro streams. 


\begin{tabular}{|c|c|c|c|c|c|c|c|}
\hline Species & 1 & 2 & 3 & Species & 1 & 2 & 3 \\
\hline Acestrorhynchus lacustris & & & & Leporinus octofasciatus & & & \\
\hline Ageneiosus ucayalensis & & & & Loricaria prolixa & & & \\
\hline Ageneiosus valenciennesi & & & & Loricaria sp. & & & \\
\hline Ancistrus sp. & & & & Loricariichthys platymetopon & & & \\
\hline Apareiodon affinis & & & & Megalancistrus aculeatus & & & \\
\hline Aphyocharax dentatus & & & & Megalonema platanus & & & \\
\hline Apteronotus sp. & & & & Myloplus tiete & & & \\
\hline Astyanax altiparanae & & & & Parauchenipterus galeatus & & & \\
\hline Astyanax schubarti & & & & Parodon nasus & & & \\
\hline Auchenipterus osteomystax & & & & Piaractus mesopotamicus & & & \\
\hline Brycon orbignyanus & & & & $\mathbb{P}$ Pimelodella $\mathrm{cf}$. gracilis & & & \\
\hline Catathyridium jenynsii & & & & Pimelodus maculatus & & & \\
\hline Cichla monoculus & & & & Pimelodus ornatus & & & \\
\hline Cichlasoma paranaense & & & & Pinirampus pirinampu & & & \\
\hline Crenicichla britskii & & & & $\mathbb{N}$ Plagioscion squamosissimus & & & \\
\hline Crenicichla haroldoi & & & & Potamotrygon motoro & & & \\
\hline Cyphocharax modestus & & & & Prochilodus lineatus & & & \\
\hline Cyphocharax nagelii & & & & Pseudopimelodus mangurus & & & \\
\hline Eigenmannia virescens & & & & Pseudoplatystoma corruscans & & & \\
\hline Galeocharax knerii & & & & Pterodoras granulosus & & & \\
\hline Gymnotus carapo & & & & Rhaphiodon vulpinus & & & \\
\hline Hemisorubim platyrhynchos & & & & Rhinelepis aspera & & & \\
\hline Hoplerythrinus unitaeniatus & & & & Rhinodoras dorbignyi & & & \\
\hline Hoplias aff. malabaricus & & & & Roeboides paranensis & & & \\
\hline Hoplosternum littorale & & & & Salminus maxillosus & & & \\
\hline Hypophthalmus edentatus & & & & Schizodon altoparanae & & & \\
\hline Hypostomus ancistroides & & & & Schizodon borellii & & & \\
\hline Hypostomus regani & & & & Schizodon cf. anisitsi & & & \\
\hline Hypostomus sp. & & & & Serrasalmus marginatus & & & \\
\hline Iheringichthys labrosus & & & & Serrasalmus spilopleura & & & \\
\hline Leporellus vittatus & & & & Sorubim lima & & & \\
\hline Leporinus elongatus & & & & Steindachnerina insculpta & & & \\
\hline Leporinus friderici & & & & Tatia neivai & & & \\
\hline Leporinus lacustris & & & & Trachydoras paraguayensis & & & \\
\hline Leporinus obtusidens & & & & & & & \\
\hline
\end{tabular}

Figure 8 - Constancy of the species collected with nets in the sites represented by: 1. São Pedro-intermediary, 2. São Pedro-mouth and 3. Paraná.

Other species were distributed at Fig. 7A in places closer to the sampling sites where there occurred, or, if widespread, in an intermediate position between the sites (Fig. 7B). Net samples. - A total of 995 specimens were collected using gill nets.

The total CPE was 14,420. Species considered abundant were Astyanax altiparanae, Prochilodus lineatus, Acestrorhynchus lacustris, Hoplias aff. malabaricus, and Steindachnerina insculpta, which made up $66.0 \%$ of the total CPE. There was a large difference in abundance between the intermediary site $(4,741)$ and the mouth $(10,579)$. The constancy values for the species collected with nets in the two São Pedro sites and one Rio Paraná site are shown in Fig. 8. All the sites presented more occasional species than accessories and constants.

The Rio Paraná site presented 24 exclusive species, and most of the other was common to São Pedro mouth. Only Prochilodus lineatus was constant in the three sites.

Cumulative frequency is showed in Fig. 9. As observed for the sieve collections, the fauna at the São Pedro mouth did not reach an asymptote for cumulative frequency (Fig. 9). The diversity spectra are shown spatially (Fig. 10) and temporally (Fig. 11) for the net collections in the São Pedro. The first one presented a diagonal pattern and the second an almost rectangular one. 
Table 1 shows the similarity between sampling sites. The most similar sites were the Rio Paraná and the São Pedro mouth, followed by the São Pedro intermediary site.

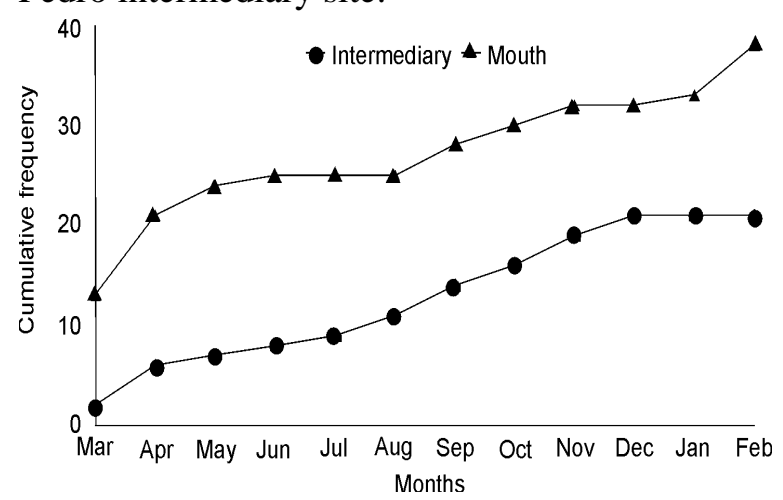

Figure 9 - Cumulative frequency for the species collected with nets in the São Pedro stream

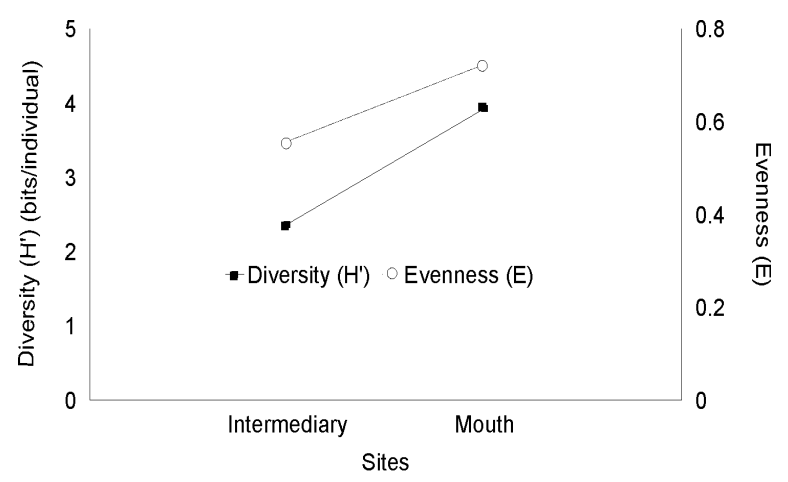

Figure 10 - Spectrum of spatial diversity based on Shannon-Wiener index $\left[H^{\prime}\right]$, and evenness $[E]$, for fishes collected with nets in the São Pedro stream.

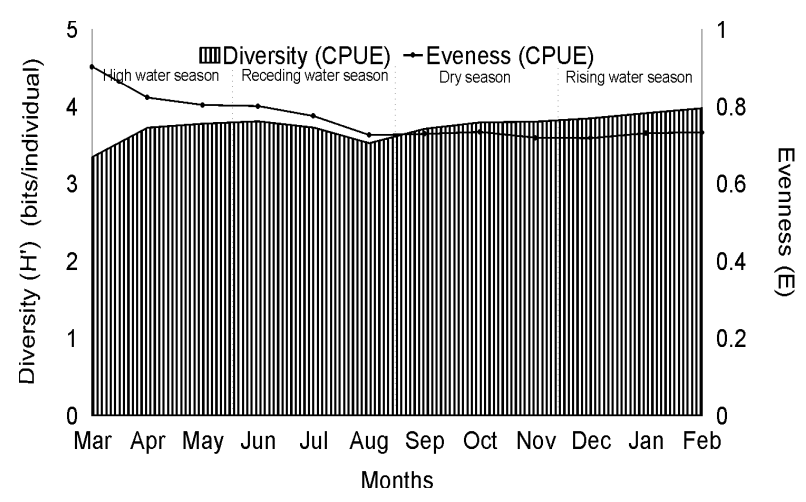

Figure 11 - Spectrum of temporal diversity based on Shannon-Wiener index [H'] (areas) and evenness $[E]$ (lines), for the species collected with nets in the São Pedro stream.
Table 1 - Similarity matrix based on Sørensen index for the sites sampled with nets in the São Pedro (S. P.) stream, and Rio Paraná.

\begin{tabular}{lccc}
\hline \multirow{2}{*}{ Sites } & \multicolumn{3}{c}{ Sites } \\
\cline { 2 - 4 } & $\begin{array}{r}\text { S. P. } \\
\text { (int.) }\end{array}$ & $\begin{array}{c}\text { S. P. } \\
\text { (mouth) }\end{array}$ & Rio Paraná \\
\hline S. P. (int.) & 1.000 & & \\
S. P. (mouth) & 0.533 & 1.000 & \\
Rio Paraná & 0.338 & 0.611 & 1.000 \\
\hline
\end{tabular}

\section{DISCUSSION}

\section{Sieves}

The higher CPE was recorded in the Caracu that had higher sampling sites (3 vs. 2 in the São Pedro). Nevertheless, even the medium CPE by stream $(5,906$ vs. 3,897 , respectively) was higher in the Caracu. It should be related to the two lentic environments made by human activity in the Caracu, where typical species such as Cichlasoma paranaense with parental care, and Phalloceros caudimaculatus with internal fertilization were always collected together with numerous juveniles.

The smaller water volume, as well as the oligotrophic conditions at the headwater might explain the lower CPE and the smaller number of species resident in relation to the subsequent downstream locations, as found by Vannote et al. (1980) for temperate rivers.

Headwaters. - These environments had a small volume of water, which explained why only a few resident species were present. Astyanax scabripinnis was constant and restricted to the headwater of the São Pedro. Besides the fact that this species is typical of headwater environments (Britski, 1972; Caramaschi, 1986), the presence of breeding individuals at this locality (Pavanelli, 1994) suggested that it was a resident. The Caracu headwater was considered a lentic environment, which explained the constancy of species that prefer low current flow, like Hoplias aff. malabaricus and Phalloceros caudimaculatus. Physical conditions in the two stream headwaters differed from each other because of human activity, which altered a lotic to a lentic environment in the Caracu. Lentic environments are not typical of headwaters. This fact led to faunistic differences, primarily regarding abundance and constancy. 
Intermediary locations. - The Caracu intermediary sampling site was semi-lotic, with some grasses along the banks. In spite of this, Gymnotus carapo, Hoplias aff. malabaricus, and Phalloceros caudimaculatus, which have been found as characteristic of lentic environments (Britski, 1972), were recorded as constants. Additional constants were Cichlasoma paranaense, generally associated with macrophytes in low-flow environments (Kullander, 1983), and Astyanax altiparanae, which had been very common and widely distributed in Paraná basin streams (Britski, 1972). It could be interesting to mention that the stream middle stretch had more species than the headwater, as also noted by Lowe-McConnell (1975) and Mosley (1987).

Mouths. - In both streams, these sampling sites showed the highest richness and number of constant species. Many of the accessory and occasional species were represented by young stages of large species, typical of the Rio Paraná, which remained there for a short time, primarily during the recruitment season. Only four constant species, A. altiparanae, Serrapinnus notomelas, Hyphessobrycon eques, and Hypostomus ancistroides, were common to the mouths of both streams. These were resident species and apparently constituted the typical ichthyofauna of this stretch of the streams of that region.

The differences demonstrated at the mouths, primarily in species richness, were attributable to the grasses near the Caracu's mouth. Vegetation occurred further upstream in the São Pedro, reducing its attractiveness to young individuals from the Paraná seeking food and shelter. Thus the results allowed us to infer that the Caracu had higher availability of microhabitats for small fishes at its mouth than the São Pedro.

Penczak et al. (1994), working in the Caracu and another stream of the same region, used other fishing gears (basically electrofishing), and different data analysis. Their results are not comparable because of the selectivity of the fishing gear employed.

The cumulative frequency data for the stream mouths did not reach an asymptote indicating that some rare species were not been collected and/or that there was some fluctuation in the environment, showing its temporary character. The contribution of the Rio Paraná ichthyofauna, composed of the highest number of species, permits us to predict future occurrences of the river fauna in this area.

Margalef (1986) discussed measurements of spatial diversity, representing a diversity spectrum. This could form different patterns for natural populations. The most common pattern was the diagonal, which indicated heterogeneity along the environment analyzed, and the rectangular, which suggested that the samples were formed basically by the same species in the same proportions. The results of this study showed a diagonal pattern, where the ichthyofauna diversity increased from the headwater to the mouth in both streams. Lowe-McConnell (1975; 1987) and Gorman and Karr (1978) suggested that the stream's upper regions are relatively homogeneous environments, with lower habitat complexity and species numbers. Thus, in areas closer to the mouth, the environment becomes complex, offering physical conditions for sheltering a larger number of species. Moreover, the proximity to the Rio Paraná led to faunal mixing, where the main channel contributed to the increase in species diversity.

In the Caracu, there was a slight decrease in the diversity index in the receding and dry water seasons, which, like evenness, increased during the rest of the year. The little peaks were caused by increase in the species number in these phases of the hydrological cycle, when there was greater environmental heterogeneity, suggesting that these parameters were influenced by the hydrological regime.

In the São Pedro, the diversity index and evenness tended to rise during the sampling period. During receding and dry water seasons, some of the more numerous species decreased in abundance, causing an increase in evenness. Since the spectrum shown was a cumulative measurement, it was expected that there would be an increase in species richness and a consequent increase in species diversity during the sampling period.

The correspondence analysis of the sites located in the same region of the streams suggested that the distribution of the ichthyofauna obeyed a spatial gradient. The larger similarity between the stream mouths confirmed the influence of the Rio Paraná fauna. The physical and chemical variables of the water also showed a spatial gradient along the streams (Pavanelli et al., 1997). 


\section{Nets}

The differences in CPE between the intermediary site and the mouth of the São Pedro could be explained by the fact that the mouth, in addition to being more influenced by the Paraná ichthyofauna, had a higher volume of water.

Intermediary. - This site had three constant species, A. altiparanae, Leporinus friderici, and Prochilodus lineatus, all common and typical of the Rio Paraná basin rivers. Among the accessory and occasional species were some typical of large rivers such as Brycon orbignyanus, the youngs or adults, which occasionally traveled upstream to this site, which was closer to the mouth and had lotic characteristics.

Mouth. - Net samples from the stream mouth showed similar constancy results to those from the sieves, however, with larger species.

Paraná (based on Nupélia/Finep, 1989). - The Rio Paraná had 9 constant, 13 accessory and 34 occasional species, including small, medium and large-sized species. Of the species belonging to the Rio Paraná ichthyofauna, 18 occurred only at the São Pedro mouth, showing the Rio Paraná contribution to the stream, with sporadic or even persistent species.

Only the São Pedro intermediary station reached an asymptote for species richness, as was also established using sieves. The results from the mouth showed that more species should occur in the lower part. It was notable that the Rio Paraná had 24 species that did not occur at any sampling site in the stream.

The spectrum of spatial diversity showed a diagonal pattern like that of the sieve samples, and was explainable by the difference in the environments analyzed. Similarly, the influence, as well as the higher availability of the Paraná microhabitats was confirmed in the lower parts.

The spectrum of temporal diversity indicated a low degree of influence by the hydrological regime, with a plateau beginning in April. Nets were mostly selective for large specimens and/or fishes of the Rio Paraná fauna, which belonged to migrating species that replaced each other proportionately, while the diversity did not change sharply. This indicated that the greatest influence came from the Rio Paraná fauna, and not from the flood regime.

The Sørensen index, in spite of yielding values quite close together, showed that the most similar sites were the mouth of the São Pedro and the Rio Paraná, which tended to confirm the mixture of faunas.

In summary, the ichthyofauna distribution in the streams analyzed was strongly influenced by the Rio Paraná at the spatial level, mainly in the lower parts, and by the river's hydrological regime at the temporal level. Although some species were constants, occasionals predominated. Corresponding sites in the two streams fell into groups of higher similarity. In addition to resident species, even among the more abundant or frequent ones, there were transitory individuals from the Rio Paraná fauna.

\section{ACKNOWLEDGMENTS}

We are grateful, from UFRJ, to R. I. Rios and, from Nupélia, to A. A. Agostinho, S. M. Thomaz, S. Veríssimo, L. C. Gomes and N. S. Hahn for the critical reading of the manuscript, to R. Fugi for determining the sex and gonadal stages of the fishes, to L. M. Bini for helping in the correspondence analysis, to J. L. L. Pereira for drawing the Fig. 1, and to G. Baumgartner, E. Gonçalves, G. Gumieri, S. Rodrigues, S. Veríssimo, and T. A. Paggioro for helping in the hard fieldwork. Logistic support came from Nupélia. EPC and CSP are also gratefully acknowledged for grants from CNPq.

\section{RESUMO}

A distribuição temporal e espacial da ictiofauna foi estudada em dois riachos, Caracu e São Pedro, afluentes do rio Paraná, de março de 1991 a fevereiro de 1992. Foram realizadas coletas em seis locais ao longo destes, sendo utilizadas peneiras em cinco (três no Caracu e dois no São Pedro), e redes em dois pontos do São Pedro. Um total de 6.664 exemplares pertencentes a 71 espécies foi capturado. Foi calculada a CPUE (captura por unidade de esforço) para cada aparelho de pesca. Dados de freqüência acumulada das espécies indicaram que apenas as bocas dos riachos não alcançaram uma assíntota. A análise da constância mostrou que espécies acessórias e acidentais predominaram. O espectro de diversidade espacial indicou que a diversidade 
aumentou da cabeceira para a foz dos riachos, enquanto que a diversidade temporal aumentou na estação de cheia. A análise de correspondência para os peixes coletados com peneiras e de similaridade de Sørensen para os de rede mostraram que os pontos de coleta espacialmente equivalentes são mais similares entre si do que com os pontos adjacentes do mesmo riacho.

\section{REFERENCES}

Agostinho, A. A. and Zalewski, M. (1996), A planície alagável do alto rio Paraná: importância e preservação. Maringá : EDUEM.

Britski, H. A. (1972), Peixes de água doce do Estado de São Paulo. In: Comissão Interestadual da Bacia Paraguai-Uruguai;. Faculdade de Saúde Pública da USP and Instituto de Pesca (eds.). Poluição $e$ Piscicultura. São Paulo. pp. 73-78.

Caramaschi, E. P. (1986), Distribuição da ictiofauna de riachos das bacias do Tietê e do Paranapanema, junto ao divisor de águas (Botucatu - SP). Tese de doutorado, Universidade Federal de São Carlos, São Paulo, Brasil.

Dajoz, R. (1983), Ecologia geral. Petrópolis : Vozes.

Gorman, O. T. and Karr, J. R. (1978), Habitat structure and stream fish communities. Ecology, 59 : (3), 507-15.

Jackson, D. A. (1997), Compositional data in community ecology: the paradigm or peril of proportions? Ecology, 78 : (3), 929-940.

Jeffries, M. and Mills, D. (1990), Freshwater ecology principles and applications. London : Belhaven Press.

Krebs, C. J. (1989), Ecological methodology. New York : Harper Collins Publishers.

Kullander, S. O. (1983), A revision of the South American cichlid genus Cichlasoma (Teleostei: Cichlidae). Swedish Museum of Natural History, Stockholm.

Legendre, L. and Legendre, P. (1983), Numerical ecology. Amsterdam : Elsevier Science Publishing.

Lowe-McConnell, R. H. (1987), Ecological studies in tropical fish communities. Cambridge : Cambridge University Press.

Lowe-McConnell, R. H. (1975), Fish communities in tropical freshwaters. New York : Longman Inc..

Margalef, R. (1986), Ecologia. Barcelona : Ediciones Omega.

Mosley, M. P. (1987), The classification and characterization of rivers. In. Richards, K. (ed.). River channels - Environment and Process. Oxford : Basil Blackwell Ltd. pp. 295-320.
Nupélia/Finep (1989), Relatório final do projeto de pesquisas: "Estudos limnológicos na planície de inundação do rio Paraná, nas imediações do município de Porto Rico - Paraná". Maringá : FUEM.

Pavanelli, C. S. (1994), Caracterização taxonômica e ecológica da ictiofauna de dois pequenos afluentes da margem esquerda do rio Paraná, na região de Porto Rico-PR, Brasil. Dissertação de mestrado, Universidade Federal do Rio de Janeiro, Rio de Janeiro, Brasil.

Pavanelli, C. S. and Caramaschi, E. P. (1997), Composition of the ichthyofauna of two small tributaries of the Paraná river, Porto Rico, Paraná State, Brazil. Ichthyol. Explor. Freshwaters, 8 : (1), 23-31.

Pavanelli, C. S.; Roberto, M. C. and Bini, L. M. (1997), Spatial and temporal variation of some limnological variables of two streams, affluents of the Paraná river (Porto Rico, Paraná, Brazil). Anais do VIII Seminário Regional de Ecologia/Programa de Pós-Graduação em Ecologia e Recursos Naturais, 8, 191-197.

Penczak, T.; Agostinho, A. A. and Okada, E. K. (1994), Fish diversity and community structure in two small tributaries of the Paraná river, Paraná State, Brazil. Hydrobiologia, 294, 243-251.

Vannote, R. L.; Minshall, G. W.; Cummins, K. W.; Sedell, J. R.; Cushing, C. E. (1980), The river continuum concept. Can. J. Fish. Aquat. Sci., 37, 130-137.

Vazzoler, A. E. A. M.; Agostinho, A. A. and Hahn, N. S. (eds). (1997), A planície de inundação do alto rio Paraná. Aspectos físicos, biológicos e socioeconômicos. Maringá : EDUEM.

Received: February 15, 2001; Revised: May 03, 2002; Accepted: September 24, 2002. 